\title{
Critical Metaphor Analysis of Political Discourse in Nigeria
}

\author{
Isaiah I. Agbo ${ }^{1}$, Goodluck C. Kadiri ${ }^{1} \&$ Blessing Ugo Ijem ${ }^{2}$ \\ ${ }^{1}$ Department of English and Literary Studies, University of Nigeria, Nsukka, Nigeria \\ ${ }^{2}$ Federal University, Wukari, Taraba State, Nigeria \\ Correspondence: Goodluck C. Kadiri, Department of English and Literary Studies, University of Nigeria, \\ Nsukka, Nigeria. E-mail: goodluck.kadiri@unn.edu.ng
}

Received: March 2, 2018 Accepted: April 19, 2018 Online Published: April 21, 2018

doi: 10.5539/elt.v11n5p95 URL: http://doi.org/10.5539/elt.v11n5p95

\begin{abstract}
Metaphor is an important figure of speech copiously deployed in political discourse. In this study, we adopted the framework of Charteris-Black's (2004) Critical Metaphor Analysis (CMA) which derives from Critical Discourse Analysis (CDA).This framework is interested in exploring the implicit intentions of language users, the ideological configurations and the hidden power relations within socio-political and cultural contexts. It captures the ideological and conceptual nature of metaphor, and transmits truth alive into the hearts of the people by passion. The thrust of this study is the identification, analysis and interpretation of the ideological and conceptual metaphors in the speeches we studied that create a particular linguistic style, conceptualize the speakers' experiences and transmit their ideologies for rhetoric and argumentation purposes. The corpus of this study is limited to the political speeches of Brigadier Sani Abacha in 1984 and 1993, General Ibrahim Babangida in 1985 and 1993, M.K.O. Abiola in 1993 and 1994, and Goodluck Ebele Jonathan in 2013. The study reveals that the speakers use metaphors as tools to enact power and wield influence on their audience. There is further the use of metaphors for the purpose of argumentation thereby promoting self-ideologies and power asymmetric. Furthermore, the study shows that the speakers in the speeches we analysed use metaphors as a strategy to identify with the people so as to create a bond between them. Finally, our speakers use metaphors to manipulate their audience both mentally and conceptually, polarize between them and the conceived enemies, and dominate their audience; and conceal and conceptualize experience in order to reframe realities to suit their interests.
\end{abstract}

Keywords: metaphor, political discourse, ideology, critical metaphor analysis, critical discourse analysis

\section{Introduction}

Initially, Cognitive linguistics paid no attention to the socio-cultural situation of cognition and how it is connected to discourse. This made cognitive linguistics to appear to "be the representative of de-contextualization and naturalization of ideologically loaded phenomena" (Wei, 2016). But recently, cognitive linguistics has taken a new dimension and pays attention to the socio-cultural factors inherent in language use and the way in which it is connected to discourse. Critical Discourse Analysis (CDA) on the other hand is "primarily interested [in] and motivated by pressing social issues" (Van Dijk, 1993), and is interested in how discourse constitutes and negotiates such social issues. CDA commits itself to revealing the hidden ideology and overt intentions of text producers as well as the relationship between language and power. Wei (2016) has observed that CDA has absorbed the results from the research of cognitive linguistics and has also taken on the methodology adopted in cognitive linguistics. Critical Metaphor Analysis (CMA) has typically become the meeting point of these two fields of research because it subsumes the two fields.

Metaphor according Corbett (1965) is an implied comparison between two things that are not the same but share some features in common. Metaphor therefore may belong to different areas of life experiences. Metaphors are "the essential core of human thought and creativity..." and "to make a metaphor is also to make a political claim" (Bronowski, 1972) since the language of politics is characterized by metaphorical themes. Metaphors are thus a powerful tool for getting to the heart of political thought. Political discourse is imbued with both linguistic and conceptual metaphors, which help in the restricting of experience. Fairclough (2003) also argues that "metaphor is one resource available for producing distinct representations of the world. But it is perhaps the particular combination of different metaphors which differentiates discourses". Linguistic metaphor refers to a metaphorical expression, which is also the surface realization of underlying conceptual metaphor. Alan Cienki 
(2005) agrees to this when he says that research in critical linguistics has proven that metaphorical expressions in language about a particular domain has the capacity to reflect an underlying meaning in terms of another. Linguistic metaphors are ornaments for creating a peculiar linguistic style where one thing is substituted for another. Linguistic metaphors refer to metaphorical expressions, which are also the surface realization of underlying conceptual metaphors .Conceptual metaphors are considered as part of the human conceptual system and emphasize the interaction between metaphor and what is being "metaphorised". This places metaphors on different levels and ways of usage (Hanne, 2006).

Metaphors play significant roles in political discourse. They are deployed by politicians to manage difficult situations, and to convey problematic expressions in order to avoid conflicts. In politics, there are various conceptualizations of experience in which the audience is left to infer possible metaphorical entailments. Politics is often conceptualized as contest, fighting, journey, gambling, show and sea voyage, which belong to different domains (Silva, 2014). Nation and opposition are also usually conceptualized in political discourse. Thus, "metaphor is a major and indispensable part of our ordinary, conventional way of conceptualizing the world, and ... our everyday behaviour reflects our metaphorical understanding of experience" (Lakoff, 204).

\subsection{Theoretical Perspective}

Critical Metaphor Analysis (CMA), as an approach to metaphor analysis aims at revealing the implied intentions and ideologies of language users (Charteris-Black, 2004) as well as the conceptual nature of metaphor. Furthermore, this approach according to Wei Li (2016) "also brings metaphor back into the traditional view of metaphor, a branch of philosophy, where metaphor was treated as a way of argumentation as well as a way of composition and style". The essence of metaphor in political speeches is to influence the opinion of the audience through persuasion and maintain solidarity. The examination of the context where metaphorical expressions occur facilitates the understanding of such metaphors and the purpose which it is intended to achieve in that communicative event.

Charteris-Black's (2004) framework for metaphor analysis suggests that in metaphor analysis, the linguistic, semantic, cognitive, and pragmatic criteria should be combined in order to effectively account for metaphor in any linguistic expression. The framework we employed to analyze metaphoric expressions in this paper combines the components of linguistic, cognitive, and pragmatic criteria since one component cannot sufficiently account for the metaphoric expressions in the political speeches that form the corpus of our data. It is on the premise of linguistic, pragmatic and cognitive criteria that Charteris-Black (2004) gives comprehensive definition of metaphor to avoid controversy over what should constitute a metaphoric expression thus:

\subsubsection{Linguistic Criteria}

A metaphor is a word or phrase that causes semantic tension by:

1). Reification - referring to something that is abstract using a word or phrase that in other contexts refers to something that is concrete.

2). Personification - referring to something that is inanimate using a word or phrase that in other contexts refers to something that is animate.

3). Depersonification - referring to something that is animate using a word or phrase that in other contexts refers to something that is inanimate.

\subsubsection{Pragmatic Criteria}

A metaphor is an incongruous linguistic representation that has the underlying purpose of influencing opinions and judgments by persuasion; this purpose is often covert and reflects speaker intentions within particular contexts of use.

\subsubsection{Cognitive Criteria}

A metaphor is caused by (and may cause) a shift in the conceptual system. The basis for the conceptual shift is the relevance of, or psycho- logical association between, the attributes of the referent of a linguistic expression in its original source context and those of the referent in its novel target context. This relevance or association is usually based on some previously unperceived similarity between the referents in those contexts.

He further redefines metaphor based on the above three criteria thus:

A metaphor is a linguistic representation that results from the shift in the use of a word or phrase from the context or domain in which it is expected to occur to another context or domain where it is not expected to occur, thereby causing semantic tension. It may have any or all of the linguistic, pragmatic and cognitive characteristics 
that are specified above (Black, 2004).

In the analysis of political discourse, Janathan Charteris - Black (2004) suggests that Critical Metaphor Analysis (CMA), which derives from cognitive linguistics and critical discourse analysis, consists of three stages: identification, interpretation and explanation of metaphors. Metaphor identification involves determining the metaphors present in a text and whether they reveal any semantic tension between a literal source domain and a metaphorical target domain. Metaphors cause semantic tension when they occur in a context where they are not expected. Metaphor interpretation concerns itself with ascertaining the type of social relations that are constructed through the metaphors identified. Metaphor explanation on the other hand deals with the way metaphors interact within the context where they are used (Charteris-Black, 2004). Metaphor explanation addresses the issue of ideological motivations in the use of language in a political speech or text. The three stages in the methodology of metaphor analysis is in agreement to that of Cameron and Low's (1999) and Fairclough's (1995) three stages of identification, interpretation and explanation methodology of CDA. Cameron and Low (1999) opine that the three stages in the methodology of metaphor analysis involve picking samples of linguistic metaphors used in discussing the topic, making a generalization from them to arrive at the conceptual metaphors they represent, and using the results to make predictions of the thought patterns which inform people's beliefs and actions in a particular socio-cultural context.

Metaphors characterize Nigerian political speeches and are essential for the dissemination of the ideology of the producers. That is why in this study attention is given to how political actors use metaphors to justify actions, legitimate self, de-legitimate opponents, manipulate, influence and persuade their audience while projecting their personal ideology. Speakers project their ideologies metaphorically either in a positive-self projection or negative projection of others. In the extracts below, some of these metaphors are examined to highlight their usefulness in the speeches analysed since "the role of metaphors is powerful in carving concepts and thus shaping our thoughts" (Monica Petrica, 2014: 532). It is also important to add that metaphors structure our cognitive system - our knowledge of the world and exert influence on our perception of the world around us. Politicians often resort to the use of metaphors because of the capacity of metaphors to disguise and conceal particular aspects of experience and thus shape reality to suit the interests of the users.

\subsection{Existing Literature}

Charteris-Black (2004) devoted the larger portion of his book, Corpus Approaches to Critical Metaphor Analysis to examine a corpus of fifty-one inauguration speeches of US presidents from George Washington to Bill Clinton, which covered a period of about 200 years. The analysis revealed metaphoric themes in the domains of conflict,

journey, building, fire, physical environment, religion, and body parts. In US Inauguration speeches, the analysis showed that the above metaphors were deployed in the speeches in order to project covert ideology of the speakers by showing some experiences which speakers and their audience share in common. This helped the speakers to exert influence on the general public. Black further compared the metaphor used in the British Party Political Manifestos and American Presidential Inauguration Speeches. He concluded that conflict metaphors were used more in the British Party Manifesto speeches than the US Inauguration speeches for the purposes of creating $\boldsymbol{u s}$ versus them dichotomy and for positive-self representation and negative representation of others.

Bart (2012) carried a research aimed at investigating The Strategic Use of Metaphors by Political and Media Elite in the 2007-11 Belgian Constitutional Crisis. The analysis of the research revealed four types of metaphors taken from the domains of Sports, Games, War, and Transport. North-Belgian politicians and journalists deployed these metaphors to achieve their political and ideological aims of defacing opponents and encouraging the people to form a common front as a people pursuing a common goal.

Rotimi Taiwo (2010) conducted a research on "Metaphors in Nigerian Political Discourse". He employed Lakoff and Johnson's (1980) theory of conceptual metaphors in the analysis of his data. The study focused on the use of metaphors by Nigerian political actors in political discourse in Nigeria. The study revealed that Nigerian political actors were metaphorically conceptualized as political builders who build the nation. The study also revealed how politicians present the metaphor of politics as battle and as a journey. It is a battle against socio-economic problem and battle between politicians and the electorate. It is a journey towards nationhood.

Vestermark (2007) studied the metaphorical personification of America in political discourse. She adopted the Cognitive - Semantic Approach of Lakoff and Johnson (1980). She focused on the personification of America in the first inauguration addresses of Ronald Reagan (1981), George H.W. Bush (1989), Bill Clinton (1993) and George, W. Bush (2001). She examined the way they used metaphors to send messages to their audience. In her analysis she identified conceptual metaphors used in the speeches and how they were used to personify a non-human entity, that is, America. Her analysis showed that the world was conceptualized as a community, the 
nation as a person and the nation as a human being. She concluded that the speakers used conceptual metaphors in their inauguration speeches to personify America and to project their personal ideology.

Mouna Hamrita (2016) employed the theories of Critical Discourse Analysis and Conceptual Metaphor Theory to study The Metaphorical and Ideological Representation of the Political Opponent in the Hardline Islamist Discourse in Tunisia. The aim of the research was to study the ideological connotations of the metaphorical expressions communicated in the language of a Tunisian Hardline Islamist politician, Ridha Belhadj. The study revealed the use of metaphors of Alienation, Evil, Demon and War to represent political opponents and politics. The study concluded that metaphorical expressions as manifested in the language of politicians have the potential of having negative effects on the Tunisian post-revolution context.

Ezeifeka (2013) used the tools of critical discourse analysis, conceptual metaphor theory and critical metaphor analysis to appraise the myriad of conventional metaphors used by a privately-owned Nigerian newspaper, the Guardian, in its reportage of the Nigerian Union of Teachers' strike as a result of the teachers demand for a new salary structure. The findings revealed the newspaper's unconscious ideological solidarity with the power elite. The metaphors manifested in its attempt to act out its watchdog role in the teachers' case. The study further concluded that it was either a deliberate strategic attempt to formulate new as well as exploit pre-existing conceptual frames as repressive apparatus against the NUT demand for a special salary structure or the lack of awareness of the negative effects of these metaphors. Some of the conceptual metaphors identified in the study include SACRIFICE (TEACHERS' PROFESSION), REWARD IN HEAVEN (TEACERS'S SALARY), WAR/CONFLICT (TEACHERS' STRIKE), VILLIAN (TEACHER), DISEASE/ ILLNESS (TEACHERS' STRIKE), COG IN THE WHEEL (TEACHERS' STRIKE), DEAD ISSUE (TEACHERS' SALARY).

The current research goes beyond the identification of metaphors in the speeches. It goes a step further to interpret the way metaphors interact within the context where they are used and explains the issue of ideological motivations in the use of language in the speeches by the political actors.

\section{Method/Text Analysis}

\subsection{Metaphor of War/Battle/Contest}

The domain of war/battle/contest has remained one of the popular sources of metaphor in politics. Politics and political activities are perceived as war. The domain of war is usually employed metaphorically for all types of human struggle and conflict. Political actors often use terms and expressions common in the field such as battle, attack, fight, and strategy, victory and so on in their daily expressions both in military and non-military situations. War metaphors project the ideology of the users that politics is war as examined in the extracts below:

1) The battle for democracy in Nigeria and Africa enters decisive phase (M.K.O. Abiola).

2) My government will dedicate to the elimination of corruption (M.K.O. Abiola)

3) If a cabal of four generals can permanently overthrow the ballots of fourteen million Nigerians, then faith in the ballot box will be destroyed in Nigeria and all over Africa (M.K.O. Abiola).

4) Finally, I pay tribute to the determination of the mass of the Nigerian people, at home and aboard to fight for their true emancipation (M.K.O. Abiola).

5) Nelson Mandela fought to replace MINORITY rule with NAJORITY rule (M.K.O. Abiola).

The speaker, MKO Abiola in excerpts (1-5) conceptualizes the myriad of political struggles in Africa for democratic governance. African countries are notorious for political turmoil occasioned by people with the intent to be president for life and the consequent resistance by the masses. This resistance by the masses is metaphorically conceptualized as battle to capture the intensity and seriousness of the struggle. Moreover, that the battle for democracy has entered a decisive phase shows that the struggle has reached its peak foreshadows hope for eventual turnaround in Nigeria and Africa politics. The speaker further conceptualizes corruption as a living organism and its elimination will engender the enthronement of democracy in Nigeria and Africa. The cancellation of the June 1993 Presidential election by Babangida and his cronies is metaphorically represented as overthrow of the ballot box. Overthrow is a word found in the military domain to describe a situation where power is taken away by force from a leader. The importance of Nigeria in African political peace and stability is alluded to be the speaker and he quickly highlights the harmful effect of overthrowing democracy in Nigeria politics on the rest of African countries. This seriousness and devastating effect of political instability in Nigeria on other Africa countries is metaphorically represented in 'destroyed in Nigeria and all over Africa'. Democracy in African countries is dependent on the sustenance of democracy in Nigeria. Solidarity with Nigerians both home and abroad is established by the speaker. There is a metaphoric representation of the support he receives 
from Nigerians as a fight for true emancipation. Having endeared himself to his audience, he quickly reminds them that Nelson Mandela fought to replace minority rule with majority rule in South Africa. We are aware that Mandela never used gun or machete in his struggle for the political freedom of South Africa from apartheid, but his struggles have been metaphorically termed a fight. The implication of this assertion is to affect the mental frame of the people, manipulate them and encourage them to keep struggling until democracy emerges in Nigeria.

6) The war against indiscipline will continue ... (General Ibrahim Babangida)

7) This was so because we sought to challenge and transform extract social forces which had in the past impeded growth and development of our country (General Ibrahim Babangida).

8) We also sought to deal with the new forces to which our programme of action gave rise (General Ibrahim Babangida)

Babangida in excerpts $(6,7 \& 8)$ identifies indiscipline as a major challenge to Nigeria political stability. He thus promises his audience that the war against it will continue. To the speaker, efforts being made to stop indiscipline are tantamount to fighting a war. The use of the metaphor 'war' underscores the enormous tasks required to inculcate discipline into civilian politicians whom the speaker accuses of indiscipline. The war against indiscipline became necessary it 'had in the past impeded growth and development of our country'. Since allowing it to continue will stagnated growth and development in the country, it is therefore rational to challenge and deal with it. The speaker justifies military intervention in Nigeria politics and shifts blame to the civilian politicians. The new forces which the speaker and his we group sought to deal with are the various civil groups who were opposed to military rule. On the other hand, the metaphor, our programme of action refers to the discipline which the military claimed that it had come to instil in the masses. It was this our programme of action which led to agitations all over the country. The military thus justifies why it has deal with the new forces. The reason being that the military intention to instil discipline was misconstrued by the masses; who in turn mobilized forces against the military. The military, therefore, claimed that it was proper for it to deal with these new forces who were opposed to sanity in the polity.

9) Drug trafficking and other economic crimes such as 419 must be tackled and eliminated (Brigadier Sani Abacha).

10) Any attempt to test our will be decisively dealt with (Brigadier Sani Abacha)

In excerpt (9), Sani Abacha identifies drug trafficking and 419 as challenges to the socio-political and economic development of Nigeria. He metaphorically represents efforts to bring them to an end. To tackle and eliminate them portray military's determined efforts to deal with them. They are evil social and economic situations which required confrontation by the military in order to be defeated. In (10), the speaker hands down warning to any person or group who may try to challenge military decision. This warning is captured in the metaphorical expression, decisively dealt with. It enacts power dominance and control over the people.

11) These actions amount to a declaration of war and a deliberate attempt to undermine the authority of the Nigerian State and threaten her territorial integrity (Goodluck Jonathan).

12) They pursue their fanatical agenda of mayhem, mass murder, division and separatism (Goodluck Jonathan).

13) We have a duty to stand firm against those who threaten the sovereign integrity of the Nigerian State (Goodluck Jonathan).

14) We will hunt them down, we will fish them out, we will bring them to justice we will win this war against terror (Goodluck Jonathan).

In excerpts $(11 \& 12)$, the actions and activities of Boko Haram group are metaphorically conceptualized as a declaration of war against and threat to Nigeria. War and threat convey the sense of danger, destruction and unrest. The speaker further uses the metaphors mayhem, mass murder, division and separatism to appeal the sense and judgment of Nigerians and the international community to accept his position that the activities of Boko Haram in Nigeria amount to war against the state. These metaphors are also meant not only to derogate members of the Boko Haram sect, but also to manipulate the cognitive and mental model of his audience to align themselves with the speaker and join forces against the sect. The uses of the above metaphors also serve as justification for the actions to be taken by the speaker which he presents thus in the war metaphors in $(13 \& 14)$ : 'We have a duty to stand firm against those who threaten the sovereign integrity of the Nigerian State'. He subsequently uses war metaphors for a sheer manifestation of power, authority and dominion in the parallel structures 'we will hunt them down, we will fish them out..., we will bring them to justice..., we will win this 
war against terror'. These emotionally charged structures are not only persuasive, but also manipulative. They have been carefully selected by the speaker in his calculated efforts to sweep the audience along in the face of the heavy casualties and wanton destructions resulting from the activities of the insurgents and terrorists in north-eastern Nigeria, which instigate fear in the audience. This is a form of using language to exercise dominance and power control.

15) The third reason I must reply you in writing is that your letter is clearly a threat to national security ... (Goodluck Jonathan).

16) I have been strengthening the institutions established to fight corruption (Goodluck Jonathan).

In excerpts ( $15 \& 16)$, the speaker deploys war metaphors in his conceptualization of the letter written to him by Olusegu Obasanjo. In highlighting the potency of the letter to engender national strive, the speaker uses the metaphor threat. In order to counter Obasanjo's allegations, secure his position of authority and enjoy the support of the masses, the speaker declares 'I have been strengthening the institutions established to fight corruption' in defense of himself and his government. He identifies corruption as the enemy of the country which he has engaged in a fight for the well-being of the Nigerian State. The speaker subtly present himself as one who in the interest of the people wages war against the challenges of the people and vices in society. He diverts people's attention from the allegations levelled against him and preoccupies their mind with his anti-corruption crusade. Thus, he justifies his actions and manipulates his audience to accept him as their saviour from political, social, economic and even religious problems.

\subsection{Metaphor of Journey}

Journey is an important political metaphor that is suggestive. The nation is metaphorically conceptualized as a journey in which the people are travelers while the political leader leads the way to the desired destination of the people. The desired destination of the people is usually the goal outlined to be achieved by the people. Below are examples of journey metaphors from our corpus.

17) Nigeria has come a long way since this administration assumed power and leadership about eight years ago (General Ibrahim Babangida).

18) But because we were determined to keep faith with the deadline 27th August, 1993, for the return of civil rule ... (General Ibrahim Babangida)

19) Many have expressed fears about the apparent return of the military (General Ibrahim Babangida).

In the examples of journey metaphors above, the speaker, General Ibrahim Babangida, projects a positive image of self. According to him, Nigeria has come a long way since he assumed power in 1985. To him, he has taken Nigerian to the preferred destination. By this, what he meant is that his government was a huge success. The speaker is now determined to keep his promise for the return of civil rule on 27th August, 1993, as he earlier promised. He wants to portray himself as one who is faithful to his promises. He further dismisses the fears expressed by many Nigerians about the apparent return of the military rule in Nigerian politics, since his administration has enabled Nigeria to come a long way. However, the metaphor, the return of civil rule makes it clearer that civil rule was chased away by the military. This is captured in the metaphor the apparent return of the military. The speaker makes a promise to his audience that civil rule will eventually rule, thus neutralizing their fear of military rule. This promise was intended to douse tension in the country caused by military rule caused by the military intervention in Nigerian politics.

20) People of Nigeria, you are witnesses that I have tried to climb the highest mountain, cross the deepest river and walk the longest mile, in order to get these men to obey the will of our people (M.K.O. Abiola).

21) There is no humiliation I have not endured, no snare that has not been put in my path, no "setup" that has not been disguised for me in my endeavour to use the path of peace ... (M.K.O. Abiola).

22) All we can see are the consequences of this permanent game of military "about turns" ... (M.K.O. Abiola).

M.K.O. Abiola in the excerpts above, projects the image of himself as a democratic and a peace-loving leader. This is intended to persuade Nigerians to shun military rule because only "democracy can move our nation forward towards progress". As a peace-lover, he has "tried to climb the highest mountain, cross the deepest river and walk the longest mile in pursuance of peace and defence of the people's will. He further de-legitimates his opponents, General Babangida and his military colleagues. The speaker projects them as peace-haters who 'setup' the innocent. They are not reliable and keep changing their decisions as captured in "permanent game of military about turns". 
23) ... we must know where we are coming from so as to appreciate where we now are, and to allow us see clearly and map out where we are going (Goodluck Jonathan).

24) Within the last three years, Nigeria has emerged as the preferred destination for all

25) For the second year running, the United Nations Conference on Trade and Investments (UNCTAD) has ranked Nigeria as the number one destination for investment in Africa ... (Goodluck Jonathan).

26) ... I will continue to do my utmost to steer our ship of state towards the brighter future to which we all aspire (Goodluck Jonathan).

27) ... We will restore every part of our country to the path of peace, growth and development (Goodluck Jonathan).

In excerpt (23), Goodluck Jonathan metaphorically polarizes between his administration and the previous ones. His use of the imperative must in we must know where we are coming from so as to appreciate where we now is strategic. It calls for a critical assessment of the previous administrations which the speaker believes was bedevilled by corruption, underdevelopment and instability in the national polity. 'Where we now are' as used by the speaker is quickly explained in the metaphorical expressions in (24 \& 25): 'the preferred destination for all' and 'the number one destination for investment in Africa'. Whereas the previous administrations were clueless, the government under the leadership of the speaker is visionary and mission-minded. The speaker impresses on his audience that 'we are better than they' and should be trusted for a better tomorrow. He further commits himself in the ( 26 \& 27): 'I will continue to do my utmost to steer our ship of state towards the brighter future to which we all aspire' and 'We will restore every part of our country to the path of peace, growth and development'. He knows exactly the aspiration of his people and in order to identify with them and create a common ground he uses the pronoun ' $\boldsymbol{w e}$ '. He gives the people hope of brighter future so as to further enjoy their support. He further shows that he understands the importance of peace for any meaningful development to take place and commits himself to restoring every part of the country to 'the path of peace, growth and development.' His administration brought us to where we are now and is taking us to the promise land. Nigeria under the administration of the speaker has become a preferred destination for investment in Africa and he will continue as the captain of the ship (Nigeria) to stir Nigeria "towards the brighter future to which we all aspire". The speaker knows the destination of the country and leads the country to that destination which is the aspiration of all Nigerians. As a democrat, the speaker will follow the path of peace for growth and development.

\subsection{Metaphor Conceptualizing the Nation as a Person}

This metaphor as used by the Nigerian politicians is intended to project the love the politicians have for the nation. It projects the politicians as having the interest of the people at heart. Metaphors which conceptualize the nation as a person bind the speakers and their audience together and portray the deep love, care and concern which the speakers have for the country. The excerpts below illustrate this.

28) My hope has always been to arouse whatever remnants of patriotism are left in the hearts of these thieves of our mandate, and to persuade them that they should not allow their personal desire to rule to usher our beloved country into an era of political instability and economic ruin (M.K.O. Abiola).

29) Long live the Federal Republic of Nigeria (M.K.O. Abiola)

M.K.O. Abiola in excerpt (28) appeals to the emotions of his audience and establishes a common front with them. 'Our beloved country' as used by the speaker portrays the love he has for Nigeria. It is this deep love for Nigeria which compels the speaker to awoken the consciousness of the military to the dangers of self-interest which according to him will 'usher our beloved country into an era of political instability and economic ruin'. He systematically de-legitimates the military in the metaphorical expression 'thieves of our mandate. The possessive adjective, 'our' bind the speaker and his audience together. This force of unity established by the speaker to polarize between the speaker and his audience and the military. In excerpt (29), he wishes the country long life just as one wish one's beloved to live long.

30) These terrorists and insurgents seem determined to establish control and authority over parts of our beloved nation ... (Goodluck Jonathan).

31) You are all living witnesses to the great economic predicament and uncertainty, which an inept and corrupt leadership has imposed on our beloved nation for the past four years (Brigadier Sani Abacha).

32) ... I will like to assure you that the Armed Forces of Nigeria is ready to lay its life for our dear country (Brigadier Sani Abacha). 
33) Let me now address your attention to the major issues that confront us, so that we may, as one people, chart a future direction for our dear country (General Ibrahim Babangida).

The same sense of endearment is portrayed in excerpts (30) and (31). Goodluck Jonathan in (30) and Sani Abacha in (31) respectively conceptualize Nigeria as 'our beloved nation'. Goodluck's love for the nation is contrasted with the activities of the members of Boko Haram in (30) whom the speaker designates as terrorists and insurgents. That they are terrorists and insurgents portray them as enemies of Nigeria while Nigeria is the beloved of the speaker. Sani Abacha in (31) adopts third party endorsement and testimonial strategy to manipulate the mental model of his audience. Calling his audience as witnesses to the effects of the failure of the ousted administration justifies and legitimates military takeover of power in the country. Thus metaphors serve as justifying strategy in Nigeria political discourse. It gives politicians entrance into the hearts of the people and enables the politicians establish themselves and their positions more securely. In (32) and (33) Sani Abacha and Ibrahim Babangida revert to the use of the variant of 'beloved' that is, 'dear' in their description of Nigeria to equally woo their audience to themselves and enjoy the solidarity of their audience. In (32) Sani Abacha commits himself and members the Armed Forces to serve the people in 'I will like to assure you that the Armed Forces of Nigeria is ready to lay its life for our dear country'. Moreover, 'that the Armed Forces of Nigeria is ready to lay its life' for Nigeria is believed to be the highest point of love one can show to one's country. It is a mark of patriotism on the part of the military. Babangida in (33) recognizes the importance of the people for the smooth running of the country. This inclusion of the people is portrayed in 'the major issues that confront $\boldsymbol{u s}$, so that we may, as one people, chart a future direction for our dear country'. The speaker utilizes the inclusive strategy in order to deceive and manipulate the people to consolidate himself since we are aware that the military rule by decree and edicts. He presents himself as a democrat and portrays his government as the government of the people by the people and for the people.

The metaphors that conceptualize the nation as a person greatly loved by the politicians also polarize between political actors and their opponents. These metaphors project the ideology of positive self-representation and negative representation of the opponents. These metaphors as exemplified by the excerpts above are meant to emphasize 'our good' and 'their bad', 'our love' and 'their hatred'. These conceptual metaphors of the nation as a person are potent rhetoric strategies for winning political battles and influencing/manipulating the feelings of the unsuspecting masses.

\section{Conclusion}

The study has revealed that metaphor is pervasively used in Nigerian political discourse. Critical Metaphor Analysis (CMA) as an approach to discourse has enabled the researchers to reveal human behaviours and attitude towards language use. We have been able to expatiate on metaphor choices in political discourse which will enable the public understand the hidden intentions of language users and have awareness of social relations that are created, maintained and sustained in metaphoric expression. CMA is an interface between Critical Discourse Analysis and Critical Metaphor Theory and proved very useful in handling the cognitive aspects of discourse interpretation and explanation. CMA reveals the social and ideological dimension of metaphor.

Using Charteris-Black's (2004) framework of Critical Metaphor Analysis, the study has demonstrated that politicians resort to metaphorical expressions in their speeches to deceive and manipulate their audience both cognitively and conceptually. The study has further demonstrated that metaphors are veritable instrument in the hands of politicians to justify their actions and activities, and consolidate their positions. This study also shows that metaphors enabled the speakers project themselves as visionary and missionary leaders who have the interest of the people and the nation at heart. The study also reveals that the essence of metaphor in political speeches is to influence the opinion of the audience through persuasion and to maintain solidarity with the people. The speakers utilized metaphors to project their personal ideology, conceptualize personal experiences and derogate opponents thereby polarizing between them and their opponents. The study showed that the corpus is replete with metaphors of war, journey, builders and person which serve various purposes and were used to describe the nation, politicians, opponents, politics and political activities in Nigeria.

\section{References}

Cammaerts, B. (2012). The strategic use of metaphors by political and media elites: The 2007- 11 Belgian constitutional crisis. International journal of media \& cultural politics, 8(2/3) 229-249. https://doi.org/10.1386/macp.8.2-3.229_1

Cameron. L., \& Low, G. (1999). Researching and Applying Metaphor. Cambridge: Cambridge University Press. https://doi.org/10.1017/CBO9781139524704 
Charteris-Black, J. (2004). Corpus approaches to critical metaphor analysis. New York: Palgrave-MacMillan. https://doi.org/10.1057/9780230000612

Cienki, A. (2005). Researching Conceptual Metaphors that may underlie Political Discourse. Paper Presented at ECPR Works on Metaphor in Political Science (Grenada, Spain). http://eis.bris.ac.uk/-potfc/Grenada/papers/cienki.pdf.

Corbett, E. (1965). Classical Rhetoric for the Modern Student. New York.

Ezeifeka, R. (2013). Strategic use of Metaphors in Nigerian Newspaper Reports: A Critical Perspective. Critical Approaches to Discourse Analysis across Disciplines, 6(2), 174-192.

Fairclough, N. (1995). Critical Discourse Analysis. London: Longman.

Fairclough, N. (2003). Analyzing Discourse. Textual Analysis for Social Research. London and New York: Routledge. https://doi.org/10.1177/0957926503014001927

Hanne, M. (2006). A Phantom Enemy: Metaphors of Terrorism in Mainstream and Alternative News Media. A pro Gradu Thesis in English. University of Jyväskyla.

Li, W. (2016). Rethinking Critical Metaphor Analysis. International Journal of English Linguistics, 6(2), 92-98. https://doi.org/10.5539/ijel.v6n2p92

Lakoff, G., \& Johnson, M. (1980). Metaphors We Live By. Chicago: Chicago University Press.

Monica, P. (2014). Cognitive Metaphors in Political Discourse in Malta, Malta and the Case of EU-Membership Date. M.A. Thesis.

Mouna, H. (2016). The Metaphorical and Ideological Representation of the Political Opponent in the Hardline Islamist Discourse in Tunisia. Journal of Research in Humanities and Social Science, 4(6), 95-105.

Taiwo, R. (2010). Metaphors in Nigerian Political Discourse. Obafemi Awololowo University, Nigeria.

Silva, B. (2014). Metaphors in Political Discourse from a Cross-Cultural Perspective. IJEMS, 1(7), 3-23.

Vestermark, I. (2007). Metaphors in Politics: A Study of the Metaphorical Personification of American Political Discourse, An Extended Essay. Lulea University of Technology and Culture.

\section{Copyrights}

Copyright for this article is retained by the author(s), with first publication rights granted to the journal.

This is an open-access article distributed under the terms and conditions of the Creative Commons Attribution license (http://creativecommons.org/licenses/by/4.0/). 